\title{
A Reconnaissance of the Philosophical Problem of Knowledge from Protagoras to Kant
}

\author{
Ihejirika Cardinal ${ }^{1}$ \\ ${ }^{1}$ Department of Philosophy, University of Port Harcourt, Rivers State, Nigeria \\ Correspondence: Ihejirika Cardinal, University of Port Harcourt, Rivers State, Nigeria. \\ Email: cardinal.ihejirika@uniport.edu.ng
}

Doi: 10.23918/ijsses.v7i2p29

\begin{abstract}
This paper undertakes a survey of the development of the philosophical problem of knowledge from Protagoras to the modern period. The unabated search for the constitutive element of reality via knowledge is directed against skepticism and circumferences around the meaning and possibility of objective knowledge. This epistemic challenge prompted the polemics of Plato, Aristotle and subsequently, got re-awakened in the renaissance before becoming heightened in the modern era. Interestingly, these discordant tunes got symphonized by Kant. Hence, our enquiry traces this epistemological metamorphosis and with the aim of identifying the definitive features of each epoch including the unique theorizing of the personages involved. The researcher, consequently, sieves from these theorizations, what is epistemically significant. Having identified a skeptical loophole in Kant's postulation of an unknowable noumena, the author suggests a symbiosis of the concerns of traditional epistemology and logic as a safeguard against the resurgence of skepticism
\end{abstract}

Keywords: Reconnaissance, Survey, Epistemology, Knowledge, Problematic, Skepticism

\section{Introduction}

The philosophical problem of knowledge is as old as the philosophical enterprise itself. From the preSocratics to the ancient, down to the modern period and beyond, the problem of knowledge has directly or indirectly been at the center of every philosophical enquiry. Man, as Collins and Makowsky (1993) put it "think of ourselves as rational, choice making, masters of our actions if not our destines but in reality, we know little about the reasons for either" (p.1). It therefore behoves on philosophy and more particularly, epistemologists to strive to provide answers to basic questions about knowledge such as: what is knowledge? What are the conditions of knowledge? Can anything be known with certainty? etcetera. Epistemology as a branch of philosophy therefore borrows deep into the bottom-line issues of knowledge, with a view to liberating man from the clutches of darkness, primitivism, barbarism and unjustified beliefs. Ozumba cited in Ojong (2013) identifies the enormous challenge the foregoing constitutes to epistemic inquiries and submits that: "The task of epistemology right from ancient times to the medieval, to the modern and to the contemporary period, is to proffer explanations as to the status of our cognitive enquiries. Do they constitute knowledge or are they mere evocations of opinions? This has thrown epistemological questions into interminable controversies" (p. 238).

In response to the aforestated challenge, the early lonian thinkers posed and proffered answers to the philosophical questions namely, Ex qua material constitutui mundi - (of what material is the world made of) thus, they presupposed the possibility of knowledge. For them therefore, objective knowledge of reality is possible and attainable. Indeed, Ozumba (2002) was right when he asserted that "one thing is certain, 
namely, that, "philosophy seeks to reach the most humanly perfect conception of matter" (p. 174). The clarifications of such conceptions rightly fall under the ambit of epistemology. Yet, a little recourse to history of thoughts indicates that the philosophical problem of knowledge emerged with the birth of sophism, who in their attempt to grapple with this problem, plunged into the philosophical extremes of relativism and skepticism. Nevertheless, Socrates, Plato and especially Aristotle in the Ancient period, has affirmed the possibility of objective knowledge, rejecting the relativism and skepticism of the sophists. For medieval thinkers, objective, universal and certain knowledge remains attainable but only through a process of divine illumination.

However, the period that immediately preceded the modern era namely, the Renaissance, was characterized by attempts to free philosophy from the clutches of theology. This led to the rebirth of skepticism. The craving for the reaffirmation of objectivity and certainty in knowledge propelled the emergence of the modern era, with its protracted intellectual rivalry between rationalism and empiricism. This rivalry stalled epistemologically enquiry but for the intervention of Immanuel Kant. Our approach in this study is to first-handily attempt the definition of knowledge, then explore philosophical theorizations of different epochs and personages, which have attempted to resolve the philosophical problem of knowledge, which includes: the summarized polemics of the Sophists; the Ancient philosophers; Socrates; Plato; Aristotle; the medieval era, among whom are Saints Augustine of Hyppo and Thomas Aquinas. We will further examine the renaissance period down to the modern era, when Immanuel Kant stepped into the scene. This survey is undertaken with the sole aim of tracing how the various philosophies and the opinions of the philosophers birthed Kant's philosophy, which is often times adjudged as a resolution of this time-honoured controversy.

Nevertheless, the author proposes his novel idea of symbiotically and complementarily conjoining the concerns of the traditional epistemologist with that of the logician as a vent out of the danger posed by the unknowability of Kantian noumena, which when left unguarded, may bring back skepticism, which gives impetus to the philosophical problem of knowledge. Besides, in the process of this survey, the researcher will sieve the historical from the not-so-relevant and ahistorical trends that may constitute stumbling blocks to the objective knowing process. Our research will round off with a brief conclusion, which will further unveil more vistas for research into the problem of knowledge.

\section{What is Knowledge?}

The word, knowledge is fundamental to our present discussion. In order to avoid mere logic-chopping, assigning any particular definition to it, becomes itself problematic. This is because no singular definition of knowledge is comprehensive and all sufficing to capture all of its references. What is meant by that, is that knowledge can be defined from the absolutist, relativist, objectivist and subjectivist perspectives. Hence, to define knowledge, is to delve into a web of controversy. Pears (1971) recognizes the complicity of defining knowledge and asserts thus: "Knowledge is so fundamental and general that it includes itself in its scope" (p.2). As a result of this, the more one tries to define it, the more complicated the task becomes. Jones (1964) agrees with Pears that "an explanation of knowledge must be in terms of something more fundamental than knowledge and that obviously, is something unknown (p.21). Jones by the foregoing means that assigning a definition to knowledge entails other fundamental concepts - all of which are similarly problematic. 
Howbeit, the word, knowledge is the noun form of the verb 'to know'. To know, can mean to be certain about a thing, to learn and remember something; to be able to recognize or identify something; ability to distinguish between things; to have enough experience and training; to be intimate with something (Chamber Encyclopedia Dictionary, p. 703). According to Ozumba (2001) to know "has implicit in it, the requirements of certainty, assurance and indubility" (p.17) Ozumba adds that "knowledge can then be defined as the state of awareness of a given fact, information required through learning and experience" (p.16).

In Plato's Thaetetus, knowledge is defined as justified true belief. It could also have recalled that Socrates argued that knowledge should be more than mere perception else, knowledge and non-knowledge could be confusingly mixed up. However, Dancey claims that in the same Thaetetus, this Plato's tripatate conception of knowledge is "the standard account of knowledge around which all recent work has been done" (p.23). The necessary and sufficient conditions that must be fulfilled for there to be an instance of knowledge included: belief, truth and justification. Plato distinguishes knowledge from opinion. For Plato, knowledge derives from the Greek word 'episteme, which implies certainty, while opinion (doxa in Greek) implies the uncertain, probable and the personal. For knowledge to be properly delineated, it must be characterized by objectivity, clarity, distinctiveness and certainty.

The 'justified true belief' thesis of Plato, which is the traditional view of knowledge got challenged in 1983 by Edmund L. Gettier, who in his, is justified true belief knowledge? called the attention of the epistemological world to the inadequacy of the traditional account of knowledge through a set of thought experiments. Ojong and Okon (2013) tell us that Getteir made a case for the fourth missing condition of knowledge (p.129). This identified lacune became known as Gettier's problem, "the problem of the fourth condition, which led to the questions: "Is there some suitable fourth condition, which may be added to the three that are set forth in the traditional definition of knowledge?" (Chisholm, p.91).

In response to the dust raised by Gettier, post-Gettier epistemologists, have embarked on an endless search for a new paradigm, which could supply the missing constitutive element of knowledge. Consequently, the defeasibility, casual and the reliability theories have all been tentatively provided. While we may not in this paper detour to extensively discuss these theories and other complexities involved in the definition of knowledge. Suffice it then, that we can now appreciate the enormous implications of imposing a singular definition to knowledge hence, the philosophical problem of knowledge we presently have at hand.

\subsection{Brief Survey of the Philosophical Problem of Knowledge from Protagora to Kant}

The immediate predecessors of the Sophists namely, the pre-Socratics were not particularly interested in the problem of knowledge per se. Hence, it could rightly be affirmed that the first philosophical enquiry into the nature, meaning, possibility and certainty of human knowledge came with the emergence of the Sophists in $15^{\text {th }}$ century B.C (Jarratt, 1991, p.85). As Herrick (2005) avers: "the aimless and contradictory speculations of the pre-socratic cosmologists drew the attention of succeeding thinkers (the sophists) away from nature, towards man and the possibility of man's knowledge of reality". (p.106). The sophists abandoned the question of the primary stuff underlying all things, which preoccupied their predecessors and raised questions about the nature and possibility of knowledge. By so doing, they gave birth to epistemological problems of relativism and skepticism. 
According to Shiappa (1991), the first of the sophists, Protagoras, is popular for his introduction of philosophical relativism. In his work titled, Truth, the fragments of which were preserved by Plato, Protagoras writes: "Man is the measure of all things; of those that are in so far as they are, and those that are not in so far as they are not" (pp. 4-6). For Protagoras therefore, objective reality was non-existent. People perceive and interprete reality in different ways; hence Shiappa (1999) asserts that "there is nothing like reality in itself, but reality as it is subjectively perceived by individuals" (pp.5-7). Objective reality or reality of itself having been denied by Protagoras, the skepticism of Gorgias therefore became a logical consequence. Gorgias thought that since reality is relative to the perceiving subjects, then there is no reality of itself; and if there is no objective reality, then nothing exists. Herrick (2005), cites Gorgias thus: "Nothing exists... if something does exist, we cannot know it, we cannot teach it to others" (pp.103-104). Thus, the Sophists gave birth to two philosophical problems which defined the direction of philosophical enquiry in the epochs after them.

\subsubsection{The Ancient Philosophers}

The first group of thinkers to react to the problematic speculations of the Sophists were the ancient philosophers - Socrates, Plato and Aristotle precisely. These thinkers developed revolutionary thoughts as they sought to redefine and rediscover philosophy from intellectual stalemate - the logical consequence of relativism and skepticism (Gaines 1997, p.16).

\subsubsection{Socrates}

The first intellectual response to the philosophical problems created by the Sophists came from Socrates. Contrary to the skeptical speculations of the sophists, Socrates argues that certain and universal knowledge is attainable. According to Gaines (1997):

Socrates was in his entire lifetime committed to the task of acquisition of true and certain knowledge. He lived and died just for this singular ideal of bringing men out of ignorance into clear, certain and universal knowledge. Socrates distinguished between particular or subjective knowledge which different individuals possess and the universal or reliable knowledge, which can be elicited through rigorous intellectual processes (pp.1-5).

In the view of Jarratt (1991), Socrates was more of a moralist than an epistemologist. His speculations on knowledge were antecedents to his thoughts on morality. Socrates was convinced that only learning and in essence, true knowledge can make men live morally - ideal lives. Without true knowledge, men cannot distinguish between right and wrong. For Socrates therefore, "right doing" is synonymous to knowledge and "wrongdoing" to ignorance; hence, his popular saying, "virtue is knowledge" (pp.92-95). Morality therefore lies in people's reason not in society nor anything else.

In his lifetime craving to bring people unto true knowledge, Socrates developed two philosophical techniques: dialectics and elenchus. Dialectics as Rickless (2007) reports, entail a process of disciplined conversation or dialogue, which for Socrates, works like an intellectual midwife (pp. 88-90). Ferrari (2007) states: "Socrates used the technique of dialogue or dialectics to help people acquire true and reliable knowledge. Through this technique, Socrates elucidated the knowledge of people about a given subject matter by inducing them to clarify their ideas or opinions. At the end, he exposes the inaccuracies in their 
subjective opinions as the case may be and presents to them, the real knowledge about the subject matter" (p.156). Therefore, in the Socratic technique of dialectics, different people introduce their opinions about a subject matter one after another. Through the same process, they respond, in an attempt to clarify their opinions, till they come to a juncture, where they jettison their inaccurate subjective opinions and accept the true and universal knowledge about the given subject. The other technique used by Socrates is elenchus. According to Bunin and Tsui-James (1996), "the Socratic process of definition otherwise known as elenchus is used to get at the general or universal meaning of concepts as against the particular meaning, which people mostly hold. It is a technique that leads to clear and fixed concepts. For Socrates therefore, by means of these rigorous philosophical processes, the human reason can discover certain and universal knowledge" (pp. 97-99).

\subsubsection{Plato}

Plato, the most popular disciple of Socrates, just like his master, believed that true and certain knowledge is attainable. Like Socrates, he made a distinction between subjective opinions and certain knowledge. According to Ackrill (2011), "Plato's view about knowledge is clear enough in his theory of innatism and the doctrine of recollection. Plato taught that knowledge is innate, meaning that everyman is born with true knowledge or idea deeply stocked in his soul" (pp. 69-70). As stated by Alican and Thesleff (2013): "In the Republic, Plato used the metaphor of the sun, the analogy of the divided line and the allegory of the cave to illustrate his teachings about human knowledge contained in his theory of innatism and doctrine of recollection. Prior to birth, Plato argued, each soul existed in the world of timeless forms and essences - the abode of true knowledge" (p.88).

For Plato therefore, knowledge becomes simply a synonym to recollection. We do not learn anything new; we only recall innate ideas. This is Plato's doctrine of recollection or annamnesis. Bedu-Addo (1991) echoes this thus: "we learn nothing; never! We simply recall or remember. Every knowledge we possess, we retrieved. Through the help of the senses, we discover, identify or recognize the pre-loaded streams of ideas in our mind" (pp. 52-54). If knowledge is simply recollection as Plato has popularized, then the ability of individuals to discover these innate ideas is responsible for the differences in peoples' intellectual capacities.

\subsubsection{Aristotle}

Aristotle was the most popular disciple of Plato. Like Socrates and Plato his master, he believed that certainty in knowledge can be attained; but however, disagreed with him in terms of how and where we can obtain true knowledge (Gerson, 2007, p.108). Lawheed (2003) states that: "While Plato thought that the material world is incapable of yielding true knowledge; Aristotle conversely believed that knowledge actually begins from the material world and with the senses. Knowledge for Aristotle therefore does not consist of introspecting as Plato claimed, but looking out to the material world to discover the facts therein" (p. 205).

Aristotle argues that we do not need innate ideas or to have concepts in advance in order to make sense of particulars as Plato reasoned. Rather, as Adanson (2010) observes, we first know the particulars and through the process of abstraction from the particulars, we form concepts or universals (p.18). To be able to group particulars, Plato thought, we need to have concepts in advance. Aristotle differed from him and 
held that concepts. Are obtainable from particulars by means of abstraction. So first, as Frede (1996) would have us believe one knows particulars and subsequently, concepts or universals" (p. 65). Man, unlike the lower animals, has the capacity to detect what is common among a number of repeated similar percepts. That is, he is able to abstract, focus selectively on what is common, while ignoring the differences among them" (Gerson, 2003, pp.88-90). This can continue successively, until we get to the categories - the widest universals at the end or climax of the abstracting process. Aristotle was therefore a realist hence he saw the material world as real and as constituting objects of knowledge (unlike Plato, who was an idealist).

\subsubsection{The Medieval Era}

The medieval period in the history of philosophy was theocentric. During this epoch, there was an integration of faith and reason. According to Schoedinger (1996), the thinkers of the medieval period were theologians, whose philosophizing was tremendously influenced by their theology to the extent that philosophy became generally seen as "ancilla theologiae" - the handmaid of theology (pp. 207-209). Two great philosophers cum theologians of the medieval era are notably distinguished. They are Saints Augustine of Hypo and Thomas Aquinas.

\subsubsection{St. Augustine of Hyppo}

St. Augustine held that God speaks to man directly in a way that is not material. God does not need any material or created thing as a medium, nor any bodily shaped spiritual intermediary. Rather, Seel (2012) tells us that, he speaks by the direct impact of the truth to the minds of men instead of their bodily ears (p.126). Thus, the minds or intellects that are open to the truth, receive true ideas from God. This is the central idea in St. Augustine's doctrine of divine illumination, which was central to his theory of knowledge. As Gracia and Noone (2013) opine: "St Augustine uses the concepts of divine truth and divine wisdom synonymously. All things were made through that wisdom. This same wisdom also permeates holy souls, making them friends and prophets of God, telling them the chronicles of God's works inwardly and soundlessly" (p. 88). It was the Holy Spirit that Augustine referred to as wisdom. Holy Spirit is the source of divine knowledge. According to Duke (2007). Truth proceeds from Him. There would be no revelation, no illumination without the action of the Holy Spirit. By illumination therefore, Augustine meant the outcome of divine illumination by the Holy Spirit (p.212).

Augustine further distinguishes between our bodily senses and the sense of the inner man. Through the bodily senses, Schoedinger (2007) tell us that, we apprehend the material world, but by the sense of the inner man, we make judgment on them through divine illumination (p. 215). We apprehend material things by our bodily senses, but it is not by our bodily senses that we form a judgement on them. For we have another sense, far more important than any bodily sense, the sense of the inner man by which we apprehend what is just and what is unjust, the just by means of the 'idea' which is presented to the intellect, the unjust by the absence of it. According to Schoedinger (2007): "The working of this sense has nothing to do with the mechanism of the eye, ear, smell, taste, or touch" (p. 216).

\subsubsection{Thomas Aquinas}

In concord with the epistemology of Aristotle, Duke (2007) informs us that, Aquinas thought that there are basically two operational stages through which we obtain knowledge: the sensitive and the intellectual 
domains. Though distinct in operation and preoccupation, they are intimately related to one another (p. 176). As highlighted by Dentusla (2009):

Thomas Aquinas agrees with Aristotle that knowledge is gotten through two stages: sensitive and intellective. The former focuses on the individual or particular things, while the latter is preoccupied with the universal, the idea, the intelligible. But these two domains are operationally related because the intellect cannot attain any idea if the sense do not provide the material for such. This is exactly what Aquinas expressed in his popular adage: nihil est in intellectu quod prius non fuerit in sensu (p.58)

Like Aristotle, Aquinas argues that the particular or individual object of knowledge is potentially universal. Thus, it is matter that makes the form individual; hence, when the matter that individualizes it, is gotten rid of, it becomes universal (Dentusla 2009: p.98). Therefore, the intellect has the potential to illuminate the phantasm or data supplied by the senses. Through this process of illumination, individual form is dematerialized and made intelligible or universal (Aquinas, Summa Theologiae). This is a consistent representation of the abstraction process in Aristotle. Duke (2007) therefore concludes that, "As far as epistemology is concerned therefore, Aquinas remains an undiluted Aristotelian" (p.180).

\subsection{The Renaissance Period}

The renaissance was a period of transition from the medieval to the modern era. According to Schmitt (2008), the word renaissance means rebirth or revival. The renaissance period therefore refers to the revival of classical arts, literature, architecture and learning, which started in Italy in the $14^{\text {th }}$ century and continued throughout Europe till the middle of the $16^{\text {th }}$ century (p.243). Among the scholars whose works determined the intellectual orientation of this period was the great Florentine artist called Leonardo da Vinci. As stated by Blum (2010), in three propositions, Leonardo da Vinci spelt out what became the basis of renaissance and early modern science and philosophy:

(1) since experience has been the mistress of whoever has written well, I take her as my mistress and to her on all points make my appeal. (2) instrumental or mechanical science is the noblest and above all others the most useful, seeing that by means of it all animated bodies which have movement perform all their action. (3) there is no certainty where one can neither apply any of the mathematical sciences nor any of those which are based upon the mathematical sciences (pp. $178-188$ ).

These Da Vincian propositions became the platform upon which the decisive early modern science and philosophy works were developed: Bacon's empiricism from the first; Thomas Hobbes mechanistic philosophy from the second; and from the third; the works of Galileo and Descartes. According to Schmitt (2008), the major contribution of Francis Bacon to philosophy is his empirical-inductive method in epistemology, in which he maintained that true knowledge can be acquired through induction; hence, knowledge must be based on experience. On the other hand, Galileo Galilei developed the mathematical deductive method, which implies that knowledge is solely attainable through the application of the principles of mathematics and logic (pp. 99-101). While Bacon is of the school of thought that believes that knowledge is accessible a posteriori (synthetic); Galileo is one of the foremost proponents of the apriori (analytic) worldview in epistemology. Schmitt (2008) reports that, "This a posterior - a priori dychotomy in the renaissance led to the reawakening of skepticism" (p. 112). 


\subsection{The Modern Period}

The re-emergence of skepticism was one of the most dominant factors that drove philosophy from the renaissance unto the modern era. Consequently, in the modern period, Lawhead (2003) tells us that, "the craving to reaffirm and strengthen the foundations of knowledge and philosophy generally dominated the activities of most philosophers" (pp. 133-140). This quest led to the birth of two popular epistemological schools of thought: rationalism and empiricism.

The rationalists held-on to the Galilean mathematical-deductive method thereby, maintaining that true knowledge proceeds from reason alone. Odiong (2012), states that the roots of rationalist thinking are traceable to Plato's doctrine of innatism. The rationalists like Plato argued that man is born with innate ideas or principles, which are objective and universal (p. 99). The chief proponents of rationalism are Rene Descartes, Baruch Spinoza and Gottfied Leibniz. On the other hand, empiricism sprang up as an intellectual response to the rationalist movement. As Odiong (2012) observes, "in furtherance of Francis Bacon's empirical-inductive method, empiricists presented formidable epistemological argument that logically stalled the rationalist claims. Contrary to the rationalists, they posited sense experience as the source of true knowledge" (p. 100). The founding fathers of the empiricist school include: John Locke, George Berkeley and David Hume. According to Eyo and Kalu (2002), in the attempt to negate the rationalist doctrine of innatism, Locke developed the idea of tabula rasa by which he meant that, the human mind is like a blank slate at birth. It is upon this empty slate that experience impress the data of knowledge (pp.16-19). George Berkeley on his part, rejected all claims pointing to unperceivable reality. For him, "esse est percipi" - to be is to perceive. Hence, for Berkeley, reality consists just of two categories of being: object of perception and perceiving subjects (Eyo \& Kanu, p.16). In the same vein, Hume argued that we cannot have knowledge of any reality beyond experience (Ozumba 2001, p. 79). The rationalistempiricist discord led to a state of epistemological fiasco, as the foundations of human knowledge became shaky and uncertain. All attempts to resolve this crisis were futile until the emergence of Immanuel Kant.

\subsection{Immanuel Kant}

Kant's epistemology was a mediation of the rationalist-empiricist rift. Rationalists maintained that knowledge is solely analytic a priori, while the empiricists said it is singularly synthetic some posteriori. Kant, resolving this endemic dichotomy, posits what he calls synthetic a priori knowledge (Gardner, 1999: p.26). As stated by Gardner (1999), "Kant in his transcendental idealism tries to show that knowledge is not reduceable to 'analytic apriori' as the rationalists claim, nor to 'synthetic some posteriori' as the empiricists maintained; but a complementary operation of the two realms in a new epistemic relationship with produces what he called 'synthetic a priori” (pp. 18-20).

This implies that sensory experience can produce knowledge but not without the contribution of the mind. Ozumba (2001) enthuses that "Before Kant, it was believed that objects of sensory experience imposed themselves on the human mind. Kant however argued that it is the other way round - it is the mind that imposes itself on the objects of experience" (p.80). Kant's synthetic a priori implies that the human mind plays a very active role in the cognitive process. It imposes itself, its own categories, on the objects and thus restructures them to conform to its own structure. Therefore, Gardner (1991) concludes that, "objects do not appear to us the way they are in themselves, but the way the human mind structures them to appear" (p.31). Kant further makes a distinction between the phenomena and the noumena. The former refers to 
objects of sensory experience, which offer us particular knowledge or facts about the world; but the later - the noumena, refers to (the form, these objects must take prior to any experience). They cannot be known because the human mind cannot be applied to that realm. Any attempt to stretch the mind to that length leads to illusion, parallogism and contradictions and antinomies of reasons (Gardner, 1991: p.32).

\section{Conclusion}

We have in this paper attempted an exploration of the evolution of the philosophical problem of knowledge, which is the major problematique of this study. However in the course of this examination, it is noticed that all pre-Kant philosophical theorizations and their proponents are found to have not only made more difficult the search for clarity of the problem of knowledge but they are also implicated in making intractable, the already abstruce subject by adding the biases and colouractions of their different milieu to the problem. For instance, the rationalist - empiricist discord conduced to a state of epistemological fiasco, which in turn shook the foundations of human knowledge and almost re-awaked the wanning skeptical tendencies. All attempts at an escape from this epistemic quagmire proved futile until Kant's revolutionary intervention. In order to solve the philosophical problem of knowledge, which got increasingly enmeshed and exposed to equivocal interpretations, Kant, had to establish and on a stronger pedestal, the cognitive capacity of the human mind thus sending skepticism to a comatose sleep. While acknowledging Kant's gargantuan contribution to modern science, epistemology and to philosophy in general, this present author still observes that Kantian unknowable noumena (the things in themselves), which is in contradistruction to his phenomena (objects of sensory experience - things as they appear to us) still leaves an unresolved challenge to epistemologists. If this is the case, then, the philosophical problem of knowledge rages on and the probability of a resurgence of skepticism cannot be considered an impossibility. In consequence, this author in agreement with Jonathan Chimakonam as cited in Ojong and Okon (2013) is convinced that "contemporary epistemology is organized around two major goals: (1) the long - standing goal of providing a definition of knowledge and simultaneously, responding to the challenge of skepticism (to which our study belongs) and (2) the goal of modeling the dynamics of epistemic and doxastic states" (p.245). Citing Hendricks and Symons (2002). Chimakonam states that "The first of the above goals have constituted the concern of philosophers, who rely on thought experiments, traditional conceptual analysis or intuition based methods of various kinds, which he contrasts with the philosophers, who are pursing the second goal, namely, those who are working with epistemic logic.

Nevertheless, this present researcher as above stated buys into Chimakonam's standpoint in Ojong and Okon (2013) that: "The apparent divergence of both enterprises can be reconciled to some extent once one recognizes that both goals relate to a third and possibly more general problem namely, (3) the problem of understanding the rationality of inquiry ... This problem is of equal importance to both logicians and traditional epistemologists" (p.252). Chimakolam, being convinced that dynamical treatments of epistemic logic of enquiry from epistemic logicians speak directly to this third, unifying goal. The strong point with which he buttresses his argument, is that most recently, epistemic logicians have concerned themselves with dynamical model of knowledge and enquiry. Howbeit, the extent to which this, is right or wrong will be revealed by the passage of time. 
Nevertheless, the impression created by the foregoing is that of a necessity to urgently recognize the fact that the activity of knowledge acquisition, (whatever form it may assume) is in part a logical one. It seems quite clear that while logic can save the traditional epistemologist from conceiving superstitions as knowledge or attempting the 'so called' impossible task of understanding the Kantian mysterious noumena, it equips him (the traditional epistemologist) with logic, which is the instrument that processes information in order to rightly qualify and separate that which is knowledge from non-knowledge. On the other hand, too, traditional epistemologists will in turn provide the logician with raw materials to work on and refine and this will save the entire gamut of philosophy from mere logic chopping. This symbiotic marriage and inseparability of these two, by means of epistemic logic is suggested here as a vent out of the philosophical problem of knowledge. That way, epistemologists may be on their way to interring skepticism eternally.

\section{References}

Ackrill, A. (2011). Plato's epistemology. Cambridge: Cambridge University Press.

Adamson, P. (2010) Posterior analytics: A dialogue with Plato? In V. Harte, M. McCabe, R.W. Sharples and A. Sheppard (Eds). Aristotle and the stoics reading Plato (pp. 1-19). London:Oxford University Press.

Alican, N. F., \& Thesleff, H. (2013). Rethinking Plato's forms. Jours, 47, 11-47.

Bedu-Addo, J.J. (1991). Sense experience and the argument for recollection. American Journal of Philosophy, 104(3), 228-24. Doi: 102307/294538.

Blum, P.R., (Ed.), (2020). Philosophers of the renaissance. Washington D. C.: The Catholic University of America Press.

Chisolm, R.M., (1989). Theory of knowledge. New Jersey: Prentice Hall

Dancey, J. (1981). Introduction to contemporary epistemology. Second edition. London: the Macmillan. Dentusla, A. (2009). Medieval epistemology. New York: Infiniti Press.

Duke, H. (2007). The era of church fathers. Oxford: Oxford University Press, 2007.

Epistemic Logic. (2006). In S. Hendrick S., J. Symons (Eds.), Standford Encyclopedia online. Retrieved from www.standord.plato.org.

Eyo, E., \& Kalu, M. (2002). Modern empiricism and the philosophy of John Locke, Goerge Benkeley and David Hume. Calabar: dermex

Gaines, R. (1997). Philosophy and phetoric. Pennsylvania: Penn State University Press.

Gardner, S. (1999). Kant and the critique of pure reason. London: Routledge Philosophy Guidebooks.

Gerson, L. (2003). Aristotle and other Platonists. Oxford: Oxford University Press.

Gettier, E. L. (1963). Is justified true belief knowledge? Analysis, 23(6), 21-123.

Gracia, J. G., \& Noone, T.B. (2003). A companion to philosophy in the middle ages. London: Blackwell. Herrick, J. (2005). The History and theory of rhetoric: An introduction. Boston: Allyn and Balon.

Jarratt, S. (1991). Rereading the sophists: Classical rhetoric refigured. Carbondale and Edwards Ville: Southern Illinois University Press.

Jones, P.C. (1964). Nature of knowledge. New York: The Free Press.

Odiong, E. (2012). The epistemological foundations of science. Accra: Edu Press.

Ojong, K., Okon, E.J. (Eds.) (2013). Living issues in epistemology. Uyo: E.L. Johns Publishers.

Ozumba, G. O. (2001). A concise introduction to epistemology. Calabar: Jochrisam Press.

Ozumba, G. O. (2001). A philosophical handbook for beginners: Value, application and opportunities for philosophers. Calabar: Pyramid Publishers.

Pears, D. (1971). What is knowledge? London: George Allen and Urnwin.

Randoff, C., \& Makowsky, M. (1993). The discovery of society. New York: McGraw Hill Books. Rickless, C. S. (2007). Plato's forms in transition. Cambridge: Cambridge University Press. 
Schoedinger, A. B. (1996). Readings in medieval philosophy. New York: New York University Press.

Seel, N. M. (2012) Epistemology and learning in medieval philosophy. In Seel (Ed.) Encyclopedia of the Sciences of Learning. Boston, M.A: Springer.

Shappa, E. (1991). Protagoras and logos. South Carolina: University of South Carolina.

William, F. L. (2003). The philosophical journey: An interactive approach. $2^{\text {nd }}$ edition, New York: McGraw Hill Books. 